\title{
College Football Performance and Athletic Department Revenues: The Power of Winning Tradition
}

\author{
William W. Hill, II \\ Mississippi State University - Meridian \\ Yingge Qu \\ Mississippi State University - Meridian
}

This paper investigates important relationships between college football performance and athletic department football revenues. The research draws from secondary data sources examining coaching experience, head coach salary, and recruiting performance as key antecedents to winning, and ultimately football revenues. The study also highlights the overriding influence of winning tradition on each stage of the proposed model. Further, the paper addresses the proposed performance-revenue model for both power 5 and non-power 5 football schools. The findings are different and revealing, and will help researchers and sport marketing professionals better understand the different football identities for these two football school categories. Ultimately, this paper highlights the importance of winning on athletic department football revenue generation for collegiate institutions across the country.

\section{INTRODUCTION}

The importance of winning in athletics has connections to many stakeholders. Winning means pride for the individual, pride for teammates, pride for and by fans, and pride for all who are involved (Lobpries, Bennett, \& Brison, 2018.). Winning also seems to lead to something else very importantrevenue generation. In this paper, we will examine winning performance and winning over an extended period of time (e.g., winning tradition) in the context of collegiate sports' biggest business, college football, a $\$ 10$ billion industry and growing (NCAA Athletic Department Database, 2017; USA Today Sports, 2017). The study delves into the determinants of winning performance, examining factors such as coaching experience, head coaching salary, and recruiting. Ultimately, the research connects the relationships between the determinants of winning with football revenues for athletic departments across the United States. Moreover, key differences between power-5 conference schools and non-Power 5 conference schools are noted between these two distinct football school program levels (Lavigne, 2016).

\section{POWER 5 VS NON-POWER 5}

Although "Power 5" is a more recent term, the gap between the "haves" and the "have nots" has always been evident. Power 5 schools are generally the larger, older institutions, with greater resources, who have played football for a very long time, sometimes for over 100 years. As such, these schools 
benefit from many years of football memories, the rivalries, the comradery amongst alumni, word-ofmouth popularity, and resultant resources available, all of which have been embedded in the history of the institution and its football folklore. With the 2014 policy enacted by the NCAA (Solomon, 2014), we can now clearly recognize the following conferences as Power 5 conferences: SEC, ACC, Big Ten, Pac-12 and Big 12. All other football playing conferences are considered non-Power 5 conferences.

\section{METHODOLOGY}

The data sample for this study was secured from multiple secondary databases. Key sources for each area include: football revenues (Department of Education, 2014; USA Today Sports, 2014); head coaching salaries (USA Today Sports, 2014), coaching records (NCAA Athletic Department Database, 2014), and recruiting rankings (Rivals Football Recruiting, 2014). Once secured, all data was aggregated in to a single spreadsheet, and then into SPSS, for quantitative assessment. Additionally, the data sample includes all public institutions where athletic department football revenue are made available. Therefore the sample does include data from private institutions, the military academies, and a select few public institutions. The data time period for this study seeks to examine performance for the years 2012-2014, and extends back through prior years for some conceptual definition and associated measures. The total sample included 169 football programs, 53 of which were considered "power 5" schools and 116 of which were considered "non-power 5" schools. The key conceptual definitions and the description of measures examined in this study are shown in Table 1.

TABLE 1

MODEL AND DESCRIPTIVE VARIABLES MEANS

\begin{tabular}{|c|c|c|c|}
\hline Model Variables & $\begin{array}{c}\text { Power } 5 \\
\text { Conference } \\
\text { s }(\mathbf{N}=53) \\
\end{array}$ & $\begin{array}{c}\text { Non-Power } 5 \\
\text { Conferences } \\
(\mathbf{n}=116)\end{array}$ & Measure Description \\
\hline $\begin{array}{l}\text { Winning Tradition } \\
\text { (composite) }\end{array}$ & 31 & 14 & $\begin{array}{l}\text { National Championships (NC) times } 5 \text { plus } \\
\text { Conference Championships (CC); (NC x } 5+ \\
\text { CC) prior to } 2012\end{array}$ \\
\hline $\begin{array}{l}\text { Coaching Experience } \\
\text { (years) }\end{array}$ & 21 & 23 & $\begin{array}{l}\text { Number of years of college coaching prior for } \\
\text { current head coaching positions prior to } 2012\end{array}$ \\
\hline Coaching Salary $(\$)$ & $3 \mathrm{M}$ & $410 \mathrm{~K}$ & Head Coaching Salary in 2014 \\
\hline $\begin{array}{l}\text { Recruiting } \\
\text { Performance (1-220) }\end{array}$ & 34 & 145 & $\begin{array}{l}\text { 3-year average recruiting rank of college based } \\
\text { on Rivals high school recruiting evaluation } \\
\text { services (2012-2014) }\end{array}$ \\
\hline Winning $(\%)$ & 57 & 47 & $\begin{array}{l}\text { 3-year average of winning percentage (2012- } \\
\text { 2014) }\end{array}$ \\
\hline Football Revenues & $\$ 49.8 \mathrm{M}$ & $\$ 5.8 \mathrm{M}$ & $\begin{array}{l}\text { Football revenues contributions from ticket } \\
\text { sales, merchandising, licensing, and any other } \\
\text { revenues attributable to football activities } \\
(2014)\end{array}$ \\
\hline
\end{tabular}

\section{CONCEPTUAL DEFINITIONS}

The key variables for this study are: winning tradition, coaching experience, head coaching salary, recruiting performance, winning, and football revenues, all of which are defined in this section. Along with definitions, the rationale for each associated measure is offered. 


\section{Winning Tradition of Football Program}

College football winning tradition is defined as the level of college football winning from generation to generation as manifested by conference and national championships. Since a national championship is the highest achievement in winning performance, it is estimated that one national championship is equal to five conference championships. This estimation is based on the projected effect a national championship has on alumni buzz, memories, and ultimately resources. Clearly, national championships mean more to tradition than conference championships, but both are suggested to be important. As such, the composite measure for the winning tradition of a college football program is based on the sum of conference championships plus five times the national championships that have occurred since the program's inception.

\section{Head Coaching Experience and Salary}

Coaching experience is described as a head coaches' number of years of experience coaching college football in any capacity at the college level. This experience includes the total number of years as an assistant coach or a head coach prior to becoming a head coach for the school examined in this study. The rational here is any college coaching time whether as an assistance or head coach is meaningful ultimate experience for the head coach. Thus, the coaching experience variable is represented by the sum of the number of years of total coaching experience prior to the evaluation period starting in 2012. Coaching Salary is defined as the total compensation for the head football coach during the 2012-2014 time period. For the study, we have used the salary posted for 2014.

\section{Football Recruiting Performance}

Football recruiting performance is described as the overall productivity of the football program in attracting the top-rated football players to sign a "letter of intent" to an institution. There is no adjustment for the number of recruits who do not stay in school or transfer to other teams. There is no adjustment for skill development once players arrive to campus. Nor is there an adjustment for how well teams are fulfilling needs with each recruiting class. Nevertheless, the general consensus in college football circles is the teams with the best players win more games. In this study, recruiting performance is measured by the team recruiting rankings from one of the top recruiting service (Rivals, 2014). Recruits are assigned an athletic value rating from 1 to 5 , with 5 being the best. Based on these rankings, team ranking are calculated. For each football institution, recruiting performance was measured by the 3-year average (2012-2014) of team recruiting ranking.

\section{Winning}

Winning is described as a team's success in winning college football games (scoring more points than an opponent) over the course of three football seasons. While "winning now" is obviously an important dimension of winning, the winning concept is designed to capture winning over a three year period of time. It is perceived that winning performance over a three-year time period adequately capture winning "in the moment during the time period of interest". As such, in this study the concept of winning was measured by determining the average winning percentage of each football program over the three-year period of interest. These were the 2012, 2013, and 2014 football seasons (NCAA Athletic Department Database, 2014).

\section{Football Revenues}

Football revenues is defined as all of the football activity revenues associated and collected by college athletic department as a direct result of football activities. Indirect revenues, such as revenues from increased university enrollment because of a winning football program, are not included here. Specifically, football revenue contributions are calculated in this study by determining the total of revenues from ticket sales, merchandising, licensing, and any other revenues attributable to football activities revenues (Department of Education, 2014; USA Today Sports, 2014). 


\section{PROPOSED MODEL AND RELATIONSHIPS}

The relationships proposed and illustrated in Figure 1 integrate three general areas: antecedents to winning, winning, and football revenues. A concise rationale for each hypothesis is provided.

\section{FIGURE 1 MODEL FOR FOOTBALL PERFORMANCE ON FOOTBALL REVENUES}

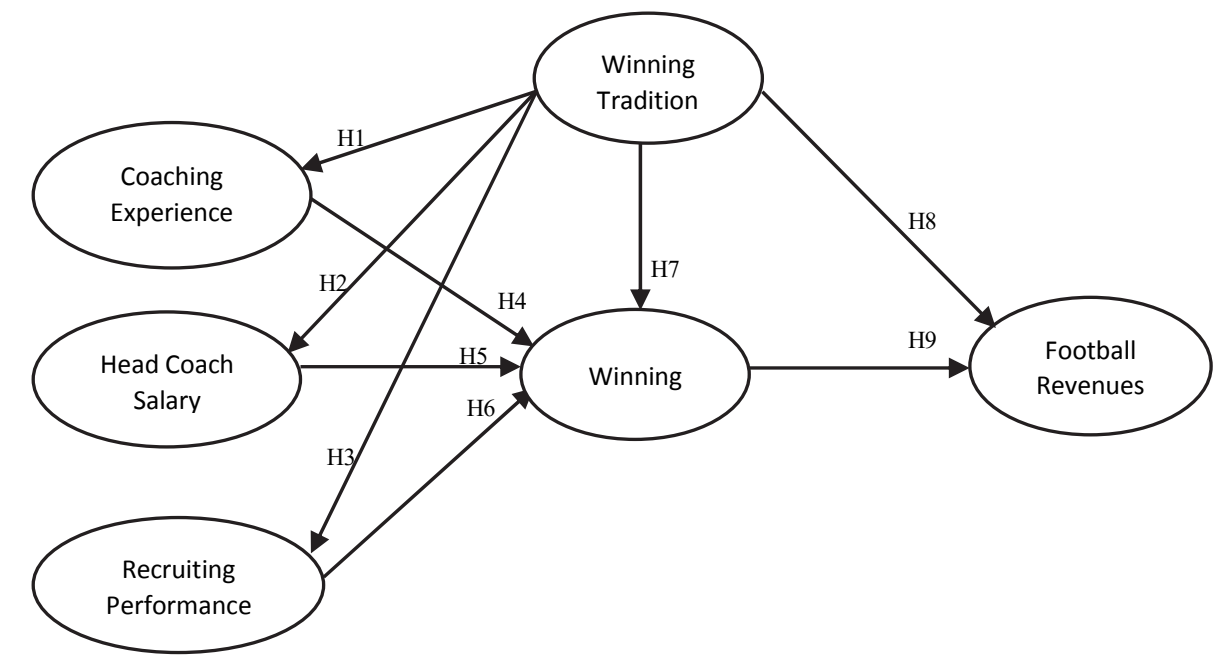

\section{Winning Tradition $\rightarrow$ Coaching Experience}

In college football, the effect of winning tradition cannot be understated. In fact, relative to winning tradition and coaching experience, it is believed that winning tradition will more easily attract experienced head coaches. Successful programs have the luxury of choosing from a larger pool of successful candidates, because successful coaches want to be associated with winning programs (Munz, 2016). As such, programs with winning traditions would expect to be less likely to risk hiring football coaches with less experience. Therefore, it is proposed that:

\section{H1: Winning Tradition will have a positive effect on Coaching Experience.}

\section{Winning Tradition $\rightarrow$ Head Coach Salary}

A winning tradition also suggests an institution and it athletic department will have the financial resources to pay head coaches at an elite level. This is true because these programs have large fan bases, a commitment to winning, and the fundraising power to hire the coaching market's most expensive football coaches. Indeed, it is suggested that the "rich get richer" by paying top dollar for the best coaches in the profession (Sheehan, 2017). As such, it is proposed that:

\section{H2: Winning Tradition will have a positive effect on Head Coach Salary.}

\section{Winning Tradition $\rightarrow$ Recruiting Performance}

Most sports-minded people believe football players want to play for winning football programs. Athletes want to win. It is a part of the competitive spirit. It only makes sense too that high school football players want to play for winning programs, and that gives winning football programs the leverage to recruit the top players (Kulha, 2012). Moreover, for high school football players who have dreams of playing professional football, playing on a winning team may help them get recognized. Additionally, from the fan's perspective, fans of winning traditions have been known to place pressure on high school athletes during the recruiting process. This is normalcy for the rich football traditions in the football crazy 
Deep South (Miller, 2017). Indeed, the fans are a part of the recruiting process too, and that comes from tradition. For this reason, it is perceived that winning programs should have an advantage in recruiting top high school talent. Thus, it is proposed that:

\section{H3: Winning Tradition will have a positive effect on Recruiting Performance.}

\section{Coach Experience $\rightarrow$ Winning}

As coaches gain experience as assistant or head coaches, they would expect to learn more about coaching - particularly the factors that improve their chance of winning. Coaching legend and three-time Super Bowl winning coach, Bill Walsh agreed, stating "Experience is really the only teacher" (Rapaport, 1993). It certainly makes sense coaching experience works, because it allows coaches the necessary time to learn the tactics that are effective and those that are not. Of course, some coaches are exceptions, and are able to win quickly through natural talents, hours of study, and gut instincts, and still others do not find great success in winning, even after staying in the coaching profession a long time. However, it is suggested that, on average, the time devoted to coaching will have a positive influence on learned success, and ultimately winning football games. For this reason, it is proposed that:

\section{H4: Coaching Experience will have a positive effect on Winning.}

\section{Head Coach Salary $\rightarrow$ Winning}

Indeed, the head coach's salary may be the culmination of a number of factors. For instance, salary may capture multiple areas like past success, belief in future success, the profitability of an athletic department, good coaching agents (Schrotenboer, et al., 2016), and timing. Most of these influences are positive, and if an athletic department believes they have a winning coach, and if they can afford it, it is perceived they are going to pay elite salary levels. There is perhaps no better example than arguably college football's greatest coach, Nick Saban, who arrived at the University of Alabama as the nation's highest paid coach, and has largely remained so, all the while compiling an unprecedented five national championship in a twelve seasons as the head coach at Alabama (Cooper, 2007; Burke, 2012; Berkowitz, 2018). So, while this is just one example, and it is clear coaching salary may represent a number of underlying coaching factors that relate to winning games, it is suggested to be a good predictor of winning. As such, it is proposed that:

\section{H5: Head Coach Salary will have a positive effect on Winning.}

\section{Recruiting Performance $\rightarrow$ Winning}

If recruiting performance can be represented by recruiting rank, and if recruiting rank is indeed accurate, then the teams who have the highest recruiting rank, should have the best players. In fact, previous studies have shown an association between recruiting and winning (Bricker \& Hanson, 2013; Evans \& Pitts, 2017; Pitts \& Evans, 2016). Coaches know very well that you have to have talented players to win at the highest level. The popular expression "It's not the X's and O's, it's the Jimmys and Joes" rings true in this assessment. That is, coaching strategy can only go so far. You have to have talented players. Therefore, it is proposed that:

\section{H6: Football Recruiting Performance will have a positive effect on Winning.}

\section{Winning Tradition $\rightarrow$ Winning}

The aura of winning tradition would seem to extend in many positive directions - in particular with passionate fans of elite college football programs. The players are not just winning for themselves, they are winning for their fans, friends, and families who value winning a great deal more than fans from other non-winning schools. In a sense, it is suggested that players will play harder for winning traditions and its 
people because they are more proud and devoted to the winning legacy that they represent. The desire to perform clearly appears to "run deep" here. For this reason, it is proposed that:

\section{H7: Winning Tradition will have a positive effect on Winning.}

\section{Winning Tradition $\rightarrow$ Football Revenues}

Football programs that have years and years of a winning tradition resulting from football championships seem to have a strong history of revenue generation with athletic departments. We would expect the fans from these programs to have great memories of winning seasons from "days gone by." Consequently, more often than not, these fans continue to attend games, continue to buy merchandise, and continue to watch their team on television, to some degree, even when the institution is not winning football games. In a sense, it is offered that the winning tradition "brand" at least partially subsidizes football revenue generation for these institutions. As such, it is proposed that:

\section{H8: Winning Tradition will have a positive effect on Football Revenues.}

\section{Winning $\rightarrow$ Football Revenues}

If winning football games is important to football fans, then the excitement of winning games would expect to bring paying fans to the stadium. There is a long history of evidence suggesting winning increases attendance, gift giving, and overall revenues for an athletic department (Stinson \& Howard, 2008; Coughlin \& Erekson, 1985). Clearly, school pride and the desire to see the winning football team and the individual football stars, is important. Beyond ticket revenues, winning likely leads to increased merchandising sales. Perhaps, the most dramatic impact to athletic department revenues comes from television revenues. For the latter, winning brings the high-paying college bowl season television revenues and conference/team bowl revenues, and helps establish leverage for future conference television contracts for member schools. Therefore, it is proposed here that:

H9: Winning will have a positive effect on Football Revenues.

\section{FINDINGS}

The correlation matrix for the variables examined in this study are shown in Table 2. A number of significant associations are present, suggesting the possibility the relationships proposed both in Figure 1 and articulated in this paper, will show significance within the overall model. Additionally, note that in Table 2, the correlation values for both the Power 5 and non-Power 5 schools are displayed separately. It is clear from Table 2 that the associations between these variables differ between these two football team category contexts in this study. For this reason, the hypothesized relationships are presented separately for power 5 and non-power 5 conferences. These results are shown in Table 3. 
TABLE 2

CORRELATION MATRIX FOR POWER 5 AND NON-POWER 5 CONFERENCE DATA

\begin{tabular}{|c|c|c|c|c|c|c|}
\hline Non-Power $5 \quad$ Power 5 & 1 & 2 & 3 & 4 & 5 & 6 \\
\hline 1. Coaching Experience (years) & & $.301 *$ & .050 & $.341 *$ & .019 & .019 \\
\hline 2. Coaching Salary $(\$)$ & .151 & & $-.578 * *$ & $.568 * *$ & $.473 * *$ & $.685 * *$ \\
\hline 3. Recruiting Performance (Rank) & -.025 & $-.751 * *$ & & $-.606^{* *}$ & $-.314 *$ & $-.713 * *$ \\
\hline 4. Winning $(\%)$ & .075 & .157 & -.123 & & .216 & $.480 * *$ \\
\hline 5. Winning Tradition (composite) & .110 & .025 & -.044 & $.292 * *$ & & $.633 * *$ \\
\hline 6. Football Revenues (\$) & .121 & $.831 * *$ & $-.790 * *$ & $.225^{*}$ & .052 & \\
\hline
\end{tabular}

TABLE 3

MODEL RESULTS

\begin{tabular}{|c|c|c|c|c|c|c|c|}
\hline \multirow[b]{2}{*}{ Hypotheses } & \multirow[b]{2}{*}{ Structural Path } & \multicolumn{3}{|c|}{ Power 5 Schools } & \multicolumn{3}{|c|}{ Non-Power 5 Schools } \\
\hline & & Est. & t-value & Support & Ext. & $\begin{array}{c}\text { t- } \\
\text { value }\end{array}$ & Support \\
\hline $\mathrm{H} 1$ & $\begin{array}{l}\text { Winning Tradition } \rightarrow \\
\text { Coaching Experience }\end{array}$ & .019 & .136 & No & .110 & 1.19 & No \\
\hline $\mathrm{H} 2$ & $\begin{array}{c}\text { Winning Tradition } \rightarrow \text { Head } \\
\text { Coach Salary }\end{array}$ & .473 & $3.87 * *$ & Yes & .029 & .306 & No \\
\hline $\mathrm{H} 3$ & $\begin{array}{c}\text { Winning Tradition } \rightarrow \\
\text { Recruiting Performance }\end{array}$ & 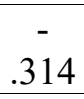 & $2.38^{-} * *$ & Yes & -.044 & -.474 & No \\
\hline $\mathrm{H} 4$ & Coach Experience $\rightarrow$ Winning & .293 & $2.84 * *$ & Yes & .024 & .267 & No \\
\hline H5 & $\begin{array}{c}\text { Head Coach Salary } \rightarrow \\
\text { Winning }\end{array}$ & .224 & $1.91^{*}$ & Yes & .139 & 1.55 & No \\
\hline H6 & $\begin{array}{l}\text { Recruiting Performance } \rightarrow \\
\text { Winning }\end{array}$ & .544 & $5.00^{-} * *$ & Yes & -.009 & -.101 & No \\
\hline $\mathrm{H} 7$ & Winning Tradition $\rightarrow$ Winning & .053 & .663 & No & .286 & $3.21 * *$ & Yes \\
\hline $\mathrm{H} 8$ & $\begin{array}{c}\text { Winning Tradition } \rightarrow \text { Football } \\
\text { Revenues }\end{array}$ & .560 & $5.65 * *$ & Yes & -.015 & -.163 & No \\
\hline H9 & Winning $\rightarrow$ Football Revenues & .341 & $3.45 * *$ & Yes & .229 & $2.41 * *$ & Yes \\
\hline
\end{tabular}

The model relationships indicating support and non-support for power 5 and non-power 5 schools are shown in Figure 2. For Hypothesis 1, the effect of winning tradition on coaching experience was not supported. Therefore, surprisingly, we did not demonstrate winning football programs are more likely to hire coaches with more coaching experience - at least in the presence of stronger predictors in this study (head coach salary, recruiting performance). This result was the finding for both power 5 and non-power 5 schools. For Hypothesis 2, the effect of winning tradition on head coach salary was supported for power 5 schools, but not for non-power 5 schools. This finding may be attributed to the fact that power 5 schools possess the resources to pay higher salaries. Moreover, non-power 5 schools may find it harder to attract top coaches, because of less prestige, regardless of money. For Hypothesis 3, the effect of winning tradition on recruiting performance was supported for power 5 schools, but not for non-power 5 schools. Again, top recruits are generally consumed by the larger power 5 schools because of the limelight and 
opportunities in these programs. So, even non-power 5 programs with great tradition may not be able to compete for top ranked recruits.

For Hypothesis 4, the effect of coaching experience on winning was supported for power 5 schools, but not for non-power 5 schools. As such, for power 5 schools, coaching experience seems to matter in winning football games. Since non-power 5 schools often serve as "coaching incubators" for great younger coaches not yet discovered by the power 5 schools, winning may happen more quickly for some, regardless of coaching experience. Additionally, since non-power 5 conferences cannot achieve the gross revenues of power 5 schools, even when winning, it may be possible that winning is not as an important factor for non-power 5 schools as a source of revenue, and coaches may be able to coach a long time without winning if they have other positive qualities. For Hypothesis 5, the effect of head coach salary on winning was supported for power 5 conferences, but not for non-power 5 conferences. Thus, for power 5 conference schools, higher paid coaches do seem to win more often. For non-power 5 schools, since head coach salaries are on a much lower scale, its effect on winning may have been dampened. For Hypothesis 6 , the effect of recruiting ranking on winning was supported for power 5 schools, but not for non-power 5 schools. Therefore, for power 5 schools, recruiting the top ranked athletes from high school seems to have a clear influence on winning college football games. For non-power 5 conference schools, most of these schools cannot compete for top recruits. Thus, since recruited athletes at non-power 5 schools are lower in rank, and likely less known, it is possible the ranking quality at this level would be less consistent or recruiting performance is simply not a factor.

Hypothesis 7 states that a winning college football traditions will have a positive influence on more winning. For power 5 conferences, surprisingly, this was not supported. However, the strength of winning tradition on other outcomes (head coach salary, recruiting performance) may explain the nonsupport for this hypothesis. For non-power 5 conferences, the effect of winning tradition on winning was supported. This result is one of the few relationships supported in the model for non-power 5 conferences. It makes sense that non-power 5 conference schools may not have the national presence for recruiting and may not have the financial resources to pay high head coaching salaries, but despite that, non-power 5 schools do have winning traditions, and this tradition does seem to have a positive influence on more winning.

For Hypothesis 8, the effect of winning tradition on football was supported for power 5 schools, but not for non-power 5 schools. Since football revenues include revenues from ticket sales, licensing, merchandising, and more, it makes sense that winning football programs with generations of fans will benefit from a larger pool of consumers who have developed traditions of visiting campuses, purchasing tickets for games, and purchasing merchandise of their favorite team or player. For non-power 5 schools, this non-support may suggest fans at this level attend and purchase similarly regardless of winning tradition. Maybe regional pride is just as important an influence on football revenues as winning tradition for non-power 5 schools. Finally, for Hypothesis 9, the effect of winning on football revenues was supported for both power 5 and non-power 5 schools. Just as reported for winning tradition, winning games in the "here and now" results in real excitement in an institution's fan base. This enthusiasm clearly results in an immediate revenue flow as fans enjoy attending games while all the while increasing spending on their team.

\section{CONCLUSIONS}

In summary, we identified key factors explaining football revenues in college football-yet the results are quite different between power 5 and non-power 5 football schools. For power 5 schools, winning tradition was supported in several of the hypothesized relationships. Winning tradition seems to be a factor in securing higher paid head coaches and creating an environment for better recruiting, and it also appears to have a direct effect on higher football revenues. For non-power 5 schools, winning tradition solely influenced winning. No other influences were supported. Perhaps the lack of both financial resources and television exposure at the non-power 5 level explains the non-support on head coach salary and recruiting performance. Additionally, it was somewhat of a surprise that winning 
tradition did not show to influence coaching experience in either of the power 5 or non-power 5 contexts. Thus, we did not show that greater winning traditions will attract more experienced coaches. Finally, the one relationship that was consistent for both power 5 and non-power 5 conference schools was the effect of winning on football revenues. Winning in the present appears to have an immediate impact on football revenues, regardless of the category of the school.

Relative to potential limitations in this research, while the findings suggest we identified key independent variables to football revenues for power 5 conference schools, we did not do the same for non-power 5 conference schools. This finding suggests future research should target more specifically how non-power 5 football schools achieve football revenues for their athletic departments. Additionally, other future research should address the influence of revenue generating football programs on their perspective institutions? For instance, do winning football programs raise university enrollment? How do football revenues support other university sports (Novy-Williams, 2017), and do certain sports complement each other? How is television changing the football revenue model? There are many research areas to probe moving forward for an industry with immense growth potential.

\section{FIGURE 2}

\section{MODEL FOR FOOTBALL PERFORMANCE ON FOOTBALL REVENUES}

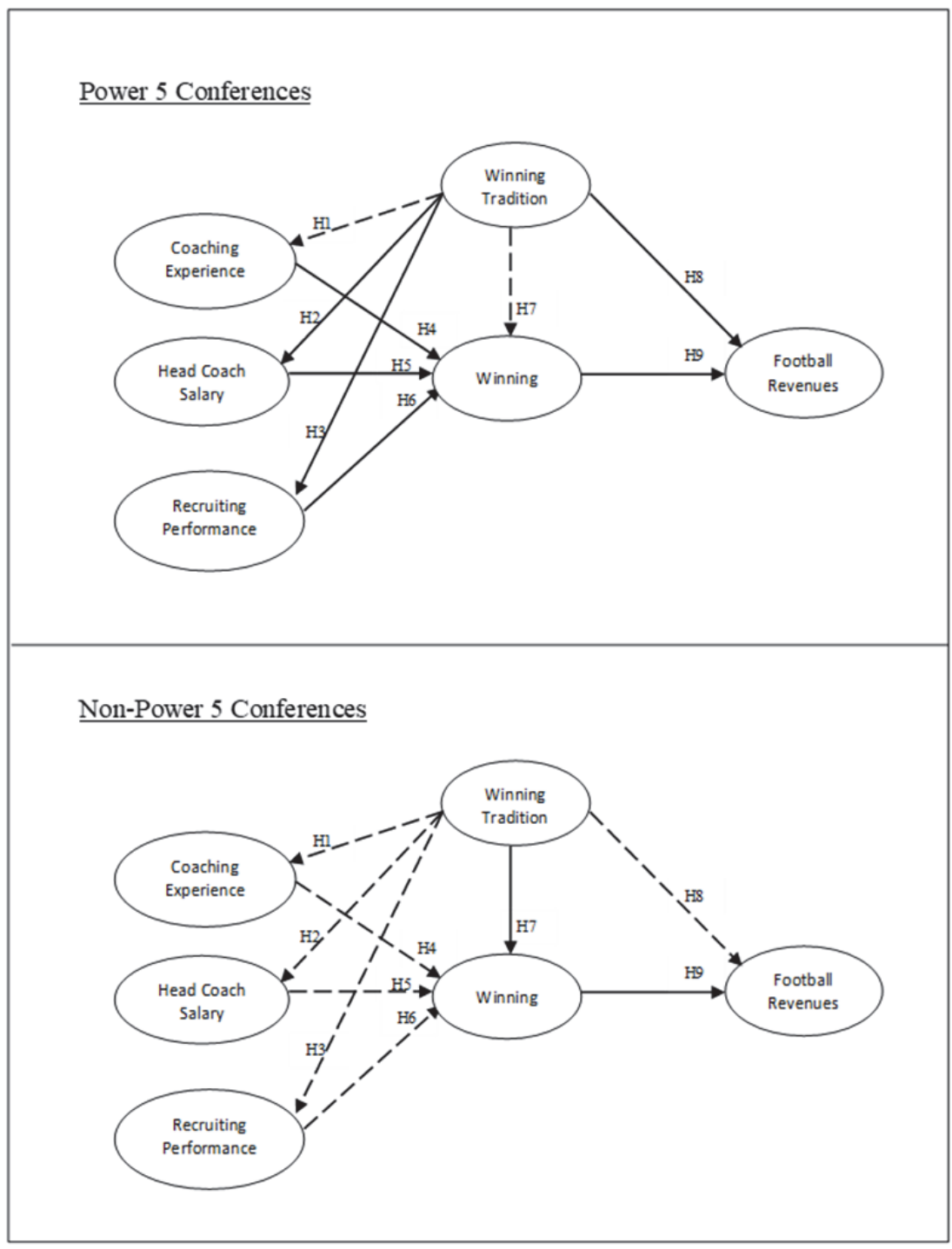




\section{REFERENCES}

Berkowitz, S. (2018). Alabama football coach Nick Saban set to make $\$ 8.3$ million this season under new contract. Retrieved from https://www.usatoday.com/story/sports/2018/07/27/nick-saban-alabamacoach-new-contract-highest-paid/852534002/

Bricker, J., \& Hanson, A. (2013). The impact of early commitment on games played: evidence from college football recruiting. Southern Economic Journal, 79(4), 971-983.

Burke, M. (2012). Nick Saban to become the highest-paid coach in college football. Retrieved from https://www.forbes.com/sites/monteburke/2012/03/26/nick-saban-to-become-the-highest-paidcoach-in-college-football/\#603bcc064186

Cooper, J. (2007). Saban rolls with Tide: former NFL coach is reportedly highest paid in college football. Retrieved from http://legacy.decaturdaily.com/decaturdaily/news/070104/coach.shtml

Coughlin, C., \& Erekson, H. (1985). Contributions to intercollegiate athletic programs: further evidence. Social Science Quarterly, 66(1), 194-202.

Evans, B. \& J. Pitts (2017). The determinants of NCAA basketball recruiting outcomes. Applied Economic Letters, 24(5), 351-354.

Kulha, A. (2012). How Much Does Tradition Impact College Football Recruiting? Retrieved from https://bleacherreport.com/articles/1360037-how-much-does-tradition-impact-college-footballrecruiting

Lavigne, P. (2016). Rich get richer in college sports as poorer schools struggle to keep up. Retrieved from http://www.espn.com/espn/otl/story/_/id/17447429/power-5-conference-schools-made-6billion-last-year-gap-haves-nots-grows

Lobpries, J., Bennett, G., \& Brison, N. (2018). How I Perform is not enough: exploring branding barriers faced by elite female athletes. Sport Marketing Quarterly, 27(1), 5-17.

Miller, A. (2017). How a single tweet by an FSU fan helped land 5-star DB Jaiden Woodbey. Retrieved from https://www.tomahawknation.com/florida-state-football-recruiting-fsu-class-commit-visitoffer/2017/12/21/16804570/jaiden-woodbey-tweet-commit-five-star-recruiting-willie-taggarttwitter-social-media

Munz, J. (2016). USM coaches tout tradition, relationships. Retrieved from https://www.hattiesburgamerican.com/story/sports/college/southern-miss/blitz/2016/11/27/usmcoaches-tout-tradition-relationships/93983342/

Novy-Williams, E. (2017). Bloomberg Quicktake College Sports. Retrieved from https://www.bloomberg.com/quicktake/college-sports-ncaa

Pitts, J., \& Evans, B. (2016). The role of conference externalities and other factors in determining the annual recruiting rankings of football bowl subdivision (FBS) teams. Applied Economics, 48(33), 3164-3174.

Rapaport, R. (1993). To build a winning team: an interview with head coach Bill Walsh. Harvard Business Review, Jan/Feb1993, 71(1), 111-120.

Rival Football Recruiting (2014). Retrieved from https://n.rivals.com

Schrotenboer, B., Berkowitz, S., \& Schnaars, C. (2016). Hiring a college football coach is expensive. Firing one is, too. Retrieved from https:/www.usatoday.com/story/sports/ncaaf/2016/10/26/college-football-coach-salary-databasebuyouts-kirk-ferentz-iowa-charlie-strong-texas/92417648/

Sheehan, R. (2017). An empirical analysis of the NCAA's competitive behavior. The Antitrust Bulletin, 62(1), 112-139.

Solomon, J. (2014). NCAA adopts new division I model giving power 5 autonomy. Retrieved from https://www.cbssports.com/college-football/news/ncaa-adopts-new-division-i-model-givingpower-5-autonomy/

Stinson, J., \& Howard, D. (2008). Winning does matter: patterns in private giving to athletic and academic programs at NCAA Division I-AA and I-AAA institutions. Sports Management Review, 11, 1-20. 
U.S. Department of Education (n.d.). Equity in Athletics Data Analysis Database. Retrieved February 6, 2016, from https://ope.ed.gov/athletics/\#/

USA Today Sports Finance (2016). Retrieved from http://sports.usatoday.com/ncaa/finances/ 